\title{
Cerebrospinal fluid cell cannibalism in metastatic breast adenocarcinoma
}

\section{Canibalismo celular no líquido cefalorraquidiano em adenocarcinoma de mama metastático} Sérgio Monteiro de Almeida ${ }^{1,2}$, Indianara Rotta ${ }^{1,2}$

Female patient with breast tumor, presenting with neurological symptoms; CSF with malignant neoplasms cells (Figure). Any type of neoplasm can spread to the leptomeninges and can be detected in the CSF. Among solid tumors, the dissemination is more frequent with breast, melanomas and lung cancer $^{1,2}$.
The positivity rate of detecting malignant cells in the CSF varies in the literature, usualy is around $24 \% \%^{1,3}$. Giant tumoral cells sometimes appear in a form suggesting tumor cell cannibalism or endocytogenesis ${ }^{4}$. Cells of this type are likely to be found after systemic and intrathecal chemotherapy ${ }^{5}$.
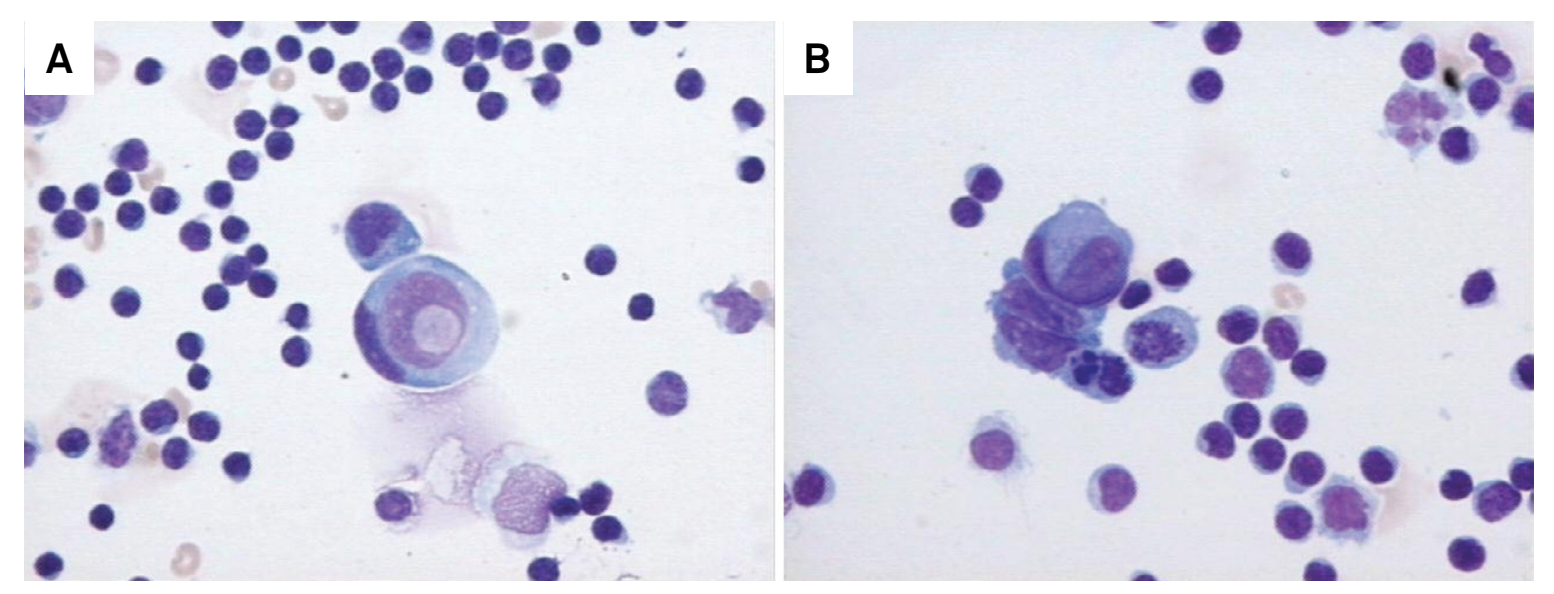

Figure. Breast adenocarcinoma with metastasis in CNS and neoplasm cell in SCF. CSF sample was concentrated by Cytospin and albumin enriched. Light microscopy (May-Grunwald/Giensa stain, 1,000x). The malignant cells usually are strange cells to the CSF environment, differing from the cells frequently seen in the CSF. (A and B) Basophilic cytoplasm, presence of degenerative vacuoles in the cytoplasm, abnormal nuclear to cytoplasmic ratio, the nucleus has hyperchromasia. Presence of normal lymphocytes reaction. The lymphocytes provides an indication of the scale. Increase in total CSF cell count is reported in 33 to $79 \%$, ranging from 18 to 685 cells $/ \mathrm{mm}^{3}$; consisting predominantly of lymphocytes and monocytes and in some cases neutrophils [3,5]. (A) The cell in the center is signet-ringed-shaped with endocytogenesis or cell cannibalism. Cell cannibalism is a diagnostic marker of malignancy, was first described in 1904, also called "bird's-eye cells" is defined as a tumor cell with in a tumor cell such that smaller tumor cells are found in the cytoplasm of the larger tumor cells with crescent-shaped nuclei [4]. (B) Cluster of neoplasic cells with different sizes, on the top signet-ringed-shaped with endocytogenesis; down a binucleated cell; on the right cell with mitoses, condensed chromatin with chromosomes not individualized suggesting prophase.

\section{References}

1. Kluge H, Wieczorek V, Linke E, Zimmermann K, Isenmann S, Witte OW. Atlas of CSF cytology. Stuttgart: Thieme; 2007.

2. Kim L, Glantz MJ. Neoplastic meningitis. Curr Treat Options Oncol. 2001;2(6):517-27. 10.1007/s11864-001-0073-x

3. $\quad$ Almeida SM, Nakanishi E, Conto AJ, Souza LP, Antonelli Filho D, Roda CD. Cerebrospinal fluid cytological and biochemical characteristics in the presence of CNS neoplasia. Arq Neuropsiquiatr. 2007;65(3B):803-9. http://dx.doi.org/10.1590/S0004-282X2007000500014

4. Oostenbrugge RJ, Twijnstra A. Presenting features and value of diagnostic procedures in leptomeningeal metastases. Neurology. 1999;53(2):382-5.

5. Gupta K, Dey P. Cell cannibalism: diagnostic marker of malignancy. Diagn Cytopathol. 2003;28(2):86-7. http://dx.doi.org/10.1002/dc.10234

'Universidade Federal do Paraná, Hospital de Clínicas, Departamento de Análises Clínicas, Curitiba PR, Brazil;

${ }^{2}$ Instituto de Pesquisa Pelé Pequeno Príncipe, Curitiba PR, Brazil.

Correspondence: Sérgio Monteiro de Almeida; Universidade Federal do Paraná, Hospital de Clínicas, Departamento de Análises Clínicas; Rua Padre Camargo, 280; 80060-240 Curitiba PR, Brasil; E-mail: sergio.ma@ufpr.br

Conflict of interest: There is no conflict of interest to declare.

Received 21 January 2015; Accepted 10 February 2015. 